Joanna Iza Belzyt

Uniwersytet Gdański

\title{
„Tak, ja KCE" - koncepcja aplikacji działania terapeutycznego KCE (wstępne nakreślenie uzasadnień opracowywanego modelu)
}

Przedstawiony artykuł jest prezentacją powstającego konstruktu teoretycznego i projektowanych badań wykorzystujących autorską koncepcję, której celem jest powstanie aplikacji KCE połączenia trzech elementów (Komunikacja-Ciało-Emocje) dla stworzenia „narzędzia” terapeutycznego.

Słowa kluczowe: Komunikacja-Ciało-Emocje, aplikacja, niepełnosprawność, oddziaływania terapeutyczne

\section{"Yes, I KCE" - concept of therapeutic application KCE (preliminary sketch of the justifications for the developed model)}

The presented article is a presentation of the emerging theoretical construct and designed research using the original concept, which aims to create a KCE application - a combination of three elements (Communication-Body-Emotions) to create a therapeutic "tool".

Keywords: Communication-Body-Emotions, application, disability, therapeutic interactions

\section{Wprowadzenie}

Każdy badacz niejednokrotnie zastanawia się nad przyszłymi badaniami, projektami, które chciałby podjąć. Część z nich ma liczne pytania, wątpliwości czy zbyt wiele pomysłów, które chciałby podjąć w badaniach.

Analizując własną sytuację dostrzegałam wielość obszarów, które były przedmiotem mojego poznania ${ }^{1}$ i które poznawać chciałam. Uświadomienie sobie, że interesujące mnie obszary nie muszą, a nawet nie powinny, być oddzielane od sie-

1 Por. wybrane: (Belzyt 2005, 2005a, 2005b, 2005c, 2005d, 2015, 2016, 2016a, 2013, 2013a). 
bie, zmieniło perspektywę i otworzyło nowe możliwości. Tym samym pozwoliło na stworzenie koncepcji (określanej docelowo aplikacją²), której celem jest wypracowanie praktycznych rozwiązań (zgodnie z ideą praktycznego wymiaru nauki, por. Seligman 2000, Kwiatek 2019), zwieńczonych powstaniem jakościowego „narzędzia" terapeutycznego ${ }^{3}$.

\section{Wprowadzenie teoretyczne w koncepcję działania terapeutycznego KCE (Komunikacja-Ciało-Emocje) ${ }^{4}$}

Każde działanie terapeutyczne wiąże się z trzema elementami składowymi, które powinny być w nim obecne. Żaden z elementów nie powinien być pominięty, ponieważ sytuacja terapeutyczna/działanie terapeutyczne nie będzie miała sensu i nie spełni swojego celu w pełnym wymiarze.

Te trzy wspomniane elementy, to w moim przekonaniu Komunikacja, Ciało, Emocje (KCE).

Na przekonanie o słuszności i ważności tej tezy mają wpływ treści, idee i działania pojawiające się w obszarze Psychologii Pozytywnej (por. Seligman, Csikszentmihalyi 2000; Shulz von Thun 2001-2007; Lubomirsky 2011; Fredrickson 2011), Interwencji Pozytywnych (por. Kwiatek 2016; Ellis 2008), Non-Violent Communication (NVC) (por. Rosenberg 2003, 2016; Tyralik-Kulpa 2016) Terapii Skoncentrowanej na Rozwiązaniach (TSR) (Jong, Berg 2007; Berger 2007; Krasiejko 2009), czy Augmentative and alternative communication, AAC) (Grycman 2014).

Do tej pory często można było spotkać oddzielanie w poszczególnych działaniach medycznych, psychologicznych, rehabilitacyjnych czy terapeutycznych aspektów związanych z komunikacją, ciałem i emocjami. Brakuje w działaniach terapeutycznych skierowanych do osób potrzebujących wsparcia spojrzenia całościowego (holistycznego) na te kwestie, które budują kompleksowy obraz człowieka. Te trzy składowe (komunikacja, ciało, emocje) wzajemnie się przenikając, zależą od siebie i oddziałują na siebie niezwykle silnie pozostając w trwałym połączeniu (szerzej na ten temat por. Belzyt 2013a).

Analizując kolejne aspekty człowieka jako obiektu badań można odnieść wrażenie, że człowiek poznając samego siebie przekonuje się i doświadcza, że jest

2 Wyjaśnienie i uzasadnienie wyboru terminu ",aplikacja” w dalszej części artykułu.

3 Określenie „narzędzie” z psychologii najczęściej kojarzone jest z wymiarem ilościowym i standaryzowaniem, natomiast $\mathrm{w}$ podjętym projekcie będzie miało wymiar jakościowy. Określenie to jest rozpoznawalne i bliskie znaczeniowo pojęciu, które będzie używane w projektowanym badaniu. Dla uniknięcia niejasności w definiowaniu, w tym artykule słowo "narzędzie" ujęte zostało w cudzysłów - szczegółowe wyjaśnienia terminów i znaczeń będą przedmiotem kolejnych artykułów.

4 Fragmenty zostały opublikowane w (Belzyt 2015), tutaj zostały przywołane jako wyjście do rozważań teoretycznych. 
całością. Podejście holistyczne (interdyscyplinarne), które przekracza granice poszczególnych dziedzin nauki pojawia się od niedawna w naszej świadomości. Człowiek nie jawi się tylko jako fizyczność, czy duchowość.

W zmieniającym się podejściu do człowieka warto podejmować rozważania dotyczące komunikacji, ciała i emocji. Połączenie to towarzyszy jednostce od zawsze, ale dopiero od niedawna staje się przedmiotem naukowego oglądu i zainteresowania.

Pomiędzy ciałem i emocjami dochodzi do wzajemnej zależność - emocje w ciele i ciało w emocjach, a zarówno ciało, jak i emocje są źródłem i odbiorcą komunikacji. Emocje wyrażane są przez ekspresję ciała, które nie znajdując ujścia zostają „zapisane" w ciele w postaci napięć, które długotrwale kumulowane doprowadzają do dolegliwości somatycznych. Ból to często efekt somatyzacji, czyli przeniesienia konfliktu wewnętrznego na poziom ciała. Somatyzacji „uczymy się" od najmłodszych lat, gdy nie ma możliwości swobodnego wyrażenia emocji, które są wypierane ze świadomości. Nie spowoduje to, że znikną, przeciwnie pojawiają się w postaci bólu czy napięć. Osoba dorosła, która w dzieciństwie doprowadziła do perfekcji wypieranie emocji traci kontakt sama z sobą i dopiero przez ból "dowiaduje się", że żyje wbrew sobie (Pawłowicz 2013; Zimbardo 1996). B. Waldenfels (2009) wskazuje, iż istnieją „choroby, które pozostają na obrzeżach naszego cielesnego Siebie i takie, które przenikają do wnętrza egzystencji” (2009: 81; por również Belzyt 2015: 109-110).

Doświadczenia świadomości własnych stanów emocjonalnych, kontroli przejawianych oznak własnych emocji i rozpoznawania emocji innych osób są kluczowymi w kontekście przystosowania społecznego i zdrowia psychicznego (Schaffer 2004). W zasadzie już od najmłodszych lat oczekuje się, że dzieci przyswoją sobie kompetencje emocjonalne, które związane są ze zdolnością do radzenia sobie zarówno z własnymi emocjami, jak i emocjami osób z najbliższego otoczenia (właściwe komunikowanie się: odczytywanie i adekwatne reagowanie na emocje). Nabycie kompetencji emocjonalnych jest równie ważne jak nabycie kompetencji intelektualnych $\mathrm{w}$ rozwoju poznawczym, ponieważ ich brak (lub opanowanie na niedostatecznym poziomie) ma poważne konsekwencje dla funkcjonowania społecznego jednostki 5 (por. Schaffer 2004).

Emocje towarzyszą każdemu działaniu człowieka, ale paradoksalnie przez wiele lat były postrzegane jako czynnik zakłócający funkcjonowanie jego (por. Zimbardo 1996) - dezorganizujący pracę umysłu, zaburzający funkcje poznawcze i zbliżający go raczej do zwierząt ${ }^{6}$ niż wynoszący „ponad (...) najwyższe ogniwo

\footnotetext{
Jest to jeden z powodów podawanych dla konieczności podejmowania badań w tym obszarze (por. Schaffer 2004).

6 Funkcje poznawcze bazują na pracy ośrodkowego układu nerwowego, a emocje angażują głównie autonomiczny układ nerwowy (prymitywny element) (Schaffer 2004).
} 
ewolucji" (Schaffer 2004: 148). Od niedawna emocje postrzegane są w kategoriach wspierania rozwoju i przystosowywania, spełniając „pozytywną funkcję, zmuszając jednostkę do zorganizowania nowych reakcji przystosowawczych w stosunku do zmienionego środowiska" (Zimbardo 1996: 353), co powoduje, że zarówno emocje, jak i rozwój emocjonalny są obszarem dynamicznych badań (por. Schaffer 2004; Denham 1998; Saarni 1999; Sroufe 1996).

Procesy poznawcze i procesy biologiczne są równie ważne dla poznania emocji. Kognitywistyczne podejście do emocji było kluczowym podejściem wśród psychologów w ostatnich latach (Cornelius 1996). Podejście to wskazuje na rolę sądów w procesie kształtowania emocji. Koncepcja ta opiera się na idei, że emocje nie powstają, dopóki nie dojdzie do oceny obiektów lub zdarzeń w danej sytuacji (Turner, Stets 2009). Zdaniem M. Arnold (1960 za: Turner, Stets 2009: 23) po wystąpieniu pobudzenia emocjonalnego występuje specyficzna reakcja ciała (fizjologiczna). W tym przypadku fizjologia „podąża” za procesem interpretacyjnym i jest raczej punktem dojścia niż wyjścia (stanowisko biologii) emocji. Niemniej jednak można stwierdzić, że bez względu na to czy reakcje biologiczne zapoczątkowują emocje czy też wynikają z doświadczeń emocjonalnych, percepcja i myśl są bardzo zaangażowane w ten proces. Kiedy ludzie zwracają uwagę na bodźce sytuacyjne i interpretują je, ich interpretacje i emocje, które temu towarzyszą, uruchamiają głębsze procesy biologiczne. I na odwrót - uruchomione bodźce biologiczne mogą podlegać namysłowi i refleksji, które mogą zmienić przepływ doświadczenia emocjonalnego. Perspektywa socjologiczna wskazuje na elementy zawierające się w emocjach (Turner, Stets 2009: 24):

1. biologiczne pobudzenie kluczowych układów ciała;

2. społecznie konstruowane definicje kulturowe i ograniczenia tego, jakie emocje powinny być doświadczane i wyrażane w danej sytuacji;

3. zastosowanie językowych etykiet dostarczanych przez kulturę do odczuć wewnętrznych;

4. zewnętrzna ekspresja emocji przez ruchy twarzy, głos i zachowania paralingwistyczne;

5. percepcja i ocena obiektów i zdarzeń sytuacyjnych.

\footnotetext{
Różnice kulturowe przejawiają się w doświadczaniu i interpretowaniu emocji, ale uznaje się, że pewne emocje są uniwersalne. Emocje pierwotne (podstawowe, bazowe) są rdzeniem, fundamentem, z którego "wyprowadzane" są wszystkie inne emocje. Emocje te są "wbudowane" w ludzką neuroanatomię, ponieważ miały wartość przystosowawczą dla ssaków a później dla naczelnych w ludzkiej linii ewolucyjnej (Izard 1992, za: Turner, Stets 2009: 26). Do emocji bazowych zalicza się szczęście, złość, strach, smutek. Emocje są niemal zawsze ograniczane i kanalizowane przez konteksty społeczno-kulturowe, ale natura emocji są napędzane przez procesy biologiczne - jeśli emocje (np. strach, złość) zostaną wzbudzone to kulturowe normy i słowniki często nie są w stanie ich ograniczyć. Zawsze trzeba brać pod uwagę biologię emocji jako kluczowy element rozumienia ich działania.
} 
Nie wszystkie elementy muszą wystąpić, aby powstały emocje. Przykładem mogą być nieświadome wspomnienia emocjonalne, które uruchamiają układy biologiczne (wbrew wizji emocji jako tworów kulturowych) i wysyłają bodźce, nie mając świadomości własnych reakcji emocjonalnych. Przy innych okazjach jednostki mogą tłumić pobudzenie emocjonalne, a w efekcie nie doświadczają emocji w ciele, ani nie ujawniają ich innym, starając się ograniczyć również kanał komunikacji niewerbalnej (Turner Stets 2009).

Ludzie zajmują pozycje w strukturach społecznych i odgrywają role kierując się posiadanymi skryptami kulturowymi. Dokonują się to dzięki poznawczym zdolnościom osób do postrzegania i oceny sytuacji (pod kątem struktury i kultury), siebie samych (jako obiektów), innych jednostek, a także reakcji fizjologicznych własnego ciała. Emocje są bowiem pierwotnie pobudzane przez aktywizację układów ciała. Pobudzenie to powstaje z poznawczej oceny siebie w relacji (komunikacji) z innymi, struktury społecznej oraz kultury (Turner, Stets 2009: 24).

Żaden z elementów - biologia (fizjologia, ciało), konstruowanie kulturowe i poznanie (mające odzwierciedlenie w procesach komunikacji) - nie są jedynymi odpowiadającymi za odczuwanie i wyrażanie emocji. Elementy te wchodzą we wzajemne złożone interakcje, których nie może wyjaśnić żadna pojedyncza dyscyplina. Tym bardziej wskazane jest rozpatrywanie ich w ujęciu łącznym (współdziałania, integralności) oraz interdyscyplinarnym. Prezentowana w tym artykule koncepcja (aplikacja) KCE wpisuje się w ten postulat.

Rozwój emocjonalny jednostki opiera się na uniwersalnych podstawach biologicznych (fizjologicznych), ale jego przebieg determinowany jest przez doświadczenia społeczne, które są zróżnicowane - $w$ różnych społecznościach okazywanie emocji może być skrajnie odmienne8, bo każda społeczność wykształca społecznie akceptowane sposoby radzenia sobie z emocjami i ich komunikowaniem. Poznanie zbioru jawnych i ukrytych wskazówek dotyczących zarządzania swoimi emocjami jest jednym z zadań socjalizacji. Reguły ekspresji emocji odnoszą się do norm kulturowych dotyczących wyrażania emocji - ich rodzaju i okoliczności, w jakich można je okazać -i pozwalają na wzajemne przewidywanie reakcji osób z grupy społecznej (Schaffer 2004). Umiejętności rozpoznawania emocji innych osób i adekwatnego reagowania na nie stają się coraz ważniejsze i wraz z kompetencjami poznawczymi stają się równorzędnymi aspektami struktury psychicznej człowieka. Kompetencje emocjonalne związane są ściśle z kompeten-

8 Lud Ifaluk (Zachodni Pacyfik) nie pozwala na okazywanie szczęścia uważając, że jest to niemoralne i prowadzi do zaniedbywania obowiązków, a także do złego zachowania i zaburzeń (Lutz 1987). Indianie Yanomamo (Wenezuela, Brazylia) cenią zaciekłość, agresję i brutalność często angażując się w spory z sąsiadami; dzieciom okazują niewiele uczuć i uczy się je zachowań agresywnych w kontaktach z innymi (Chagon 1968). Mieszkańcy Bali uważają się wszelkie wybuchy emocjonalne są szkodliwe i wychowują dzieci tak, aby unikały nawet najmniejszych oznak emocji (Bateson, Mead 1940, za: Schaffer 2004). 
cjami społecznymi, co wynika z tego, że sednem kontaktów społecznych jest właśnie umiejętność radzenia sobie z emocjami, zarówno własnymi jak i cudzymi (Halbenstadt, Denham, Dunsmore 2001; Schaffer 2004), Szczególnie jest to widoczne w kontaktach międzyludzkich, gdzie znajomości, przyjaźnie i popularność zyskują osoby, które potrafią wiązać własne emocje z emocjami innych osób. Jak wynika z badań (por. Schafer 2004; Turner, Stets 2009) osoby bardziej lubiane, mające większe "powodzenie" $w$ kontaktach międzyludzkich, bardziej popularne $i$ akceptowane społecznie a co za tym idzie bardziej kompetentne pod względem społecznym, to osoby, które:

- wypracowały konstruktywny sposób kierowania emocjami (opanowanie);

- wyraźnie komunikują innym swoje stany emocjonalne;

- dobierają trafnie właściwe przekazy emocjonalne (zgodność komunikatu werbalnego i niewerbalnego);

- korzystają z pozytywnych wyrazów emocji, poprawnie interpretujące komunikaty emocjonalne innych osób;

- potrafią komunikować nieprzyjemne stany emocjonalne w sposób akceptowalny (nieagresywny) (por. Schaffer 2004: 173).

Podsumowując powyższe rozważania, komunikacja zachodzi pod wpływem emocji (uświadomionych i nieświadomych) i wywołuje emocje, zmienia się pod wpływem emocji. Komunikując się przekazujemy emocje (a przynajmniej mamy taką intencję), aby wyrazić swoje potrzeby w celu ich zaspokojenia9.

Ciało spełnia wiele funkcji ${ }^{10}$. Ciało komunikuje się nieustannie, nawet kiedy nie pojawia się komunikacja werbalna. Komunikacja określana mianem komunikacji niewerbalnej jest przedmiotem wielu badań, obserwacji i publikacji, ale konieczne jest jej postrzeganie przez pryzmat kontekstu i intencji komunikacyjnej.

W ciele ujawniają się również emocje, podczas aktu komunikacyjnego, jak również poza nim. Ciało komunikuje stay emocjonalne i to właśnie w ciele zapisują się emocje - te pozytywne (np. eustres), jak i negatywne (np. stres), które nagromadzone tworzą napięcia, bóle, a w konsekwencji prowadzą do wielu chorób (o podłożu somatycznym).

Emocje obecne są w komunikatach, mogą je wzmacniać i uwiarygadniać lub zakłócać. Każda emocja jest komunikatem, a każdy komunikat nacechowany jest emocjonalnie.

Harmonijne współdziałanie i współwystępowanie trzech elementów (Komunikacja-Ciało-Emocje) tworzących podstawy koncepcji (aplikacji) KCE jest klu-

\footnotetext{
9 Tematyka dotycząca cech komunikacji, czynnikach wspierających i zakłócających (utrudniających) komunikację oraz potrzebach, emocjach i uczuciach (również rzekomych) zostanie przedstawiona obszerniej w kolejnym artykule, podobnie jak pozostałe części wchodzące w sklad koncepcji (aplikacji) KCE.

10 Np. o ciele jako kategorii pedagogicznej pisze P. Błajet, 2006.
} 
czem do odczuwania dobrostanu i poczucia szczęścia (por. Peterson, Seligman 2004; Seligman 2011).

Koncepcja ta jest koncepcją uniwersalną, która może znaleźć zastosowanie nie tylko w obszarze pedagogiki czy szerzej: nauk społecznych, ale również w innych dziedzinach, gdzie przydatne jest zastosowanie wiedzy dotyczącej złożonej problematyki komunikacji i emocji (por. Belzyt 2017; Belzyt, Badera 2018)11.

Omawiane trzy komponenty koncepcji (aplikacji) KCE uważam za niezwykle istotne $\mathrm{w}$ pracy z osobami z niepełnosprawnościami i szczególnie na nich planuję skoncentrować swoją uwagę badawczą. U osób z niepełnosprawnościami często nie występuje komunikacja (lub jej rozwój jest znacznie opóźniony), co nie znaczy, że nie komunikują się, że nie mają potrzeby komunikacji, że nie przejawiają intencji komunikacyjnej. Komunikują się całym swoim ciałem, biciem serca, oddechem, ciśnieniem krwi, napięciem i rozluźnieniem ciała, ruchami gałek ocznych, stanem snu i czuwania (por. Grycman 2014; Fröhlich 1998; Zaorska 2012; Baran, Mikrut 2007; Piszczek 2007; Kwiatkowska 2006; Belzyt 2015).

Zauważenie, zrozumienie i odczytywanie tych intencji jest bardzo trudne i czasochłonne, wymaga od partnera komunikacyjnego (osoby będącej w relacji) uważności, cierpliwości i wrażliwości na sygnały płynące z ciała, jak również emocje pojawiające się w związku z sytuacją komunikacyjną (sytuacją relacji).

Wrażliwość i empatia są kolejnymi czynnikami niezwykle ważnymi w sytuacji, kiedy osoby z niepełnosprawnościami mają być aktywnymi uczestnikami relacji terapeutycznych (działań terapeutycznych) i mają mieć potrzebę uczestniczenia w nich (chcieć brać czynny udział).

Sprawienie, że osoba z niepełnosprawnościami złożonymi będzie aktywnym uczestnikiem działań terapeutycznych (rola agensa), wychodząc z bierności wyuczonej czy narzuconej (rola patiensa ${ }^{12}$ ) jest wyzwaniem dla obu stron relacji terapeutycznej (por. Grycman 2014; Fröhlich 1998; Kwiatkowska 2006; Belzyt 2015; Doroszuk 2015).

Tylko w sytuacji aktywnej postawy, czyli możliwości dokonywania wyboru (nawet ograniczonego) i w sytuacji bycia w sytuacji relacji komunikacyjnej (istnienia roli nadawcy i odbiorcy), poczucia, że nadawane komunikaty są dostrzegane i rozumiane przez partnera komunikacyjnego osoba może realizować swoje potrzeby, m.in. potrzebę bycia rozumianym, potrzebę relacji, potrzebę autonomii

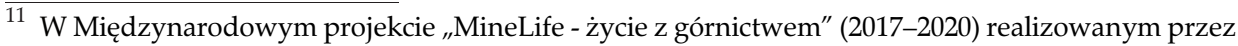
polsko-niemieckie konsorcjum $\mathrm{w}$ ramach transgranicznego programu Interreg Polska-Saksonia, finansowanego ze środków Europejskiego Funduszu Rozwoju Regionalnego dostrzeżona została rola komunikacji i emocji $\mathrm{w}$ profilaktyce, zarządzaniu u rozwiązywaniu konfliktów wywoływanych oddziaływaniami górnictwa. $\mathrm{W}$ ramach działań zaplanowanych $\mathrm{w}$ projekcie prowadzę warsztaty z obszaru psychospołecznych znaczeń i oddziaływań komunikacji oraz emocji w profilaktyce, zarządzaniu i rozwiązywaniu konfliktów.

12 Por. (Belzyt 2009). 
(por. Grycman 2014; Fröhlich 1998; Baran, Mikrut 2007; Piszczek 2007; Kwiatkowska 2006; Belzyt 2015; Rosenberg 2006). Kiedy występują zakłócenia niezależne od stron zaangażowanych w proces komunikacji, to znaczącym dla jej przebiegu i jakości staje się intencja oraz gotowość do podjęcia próby zrozumienia komunikatów osób z niepełnosprawnościami i nadawania im znaczeń komunikacyjnych (por. Grycman 2014; Fröhlich 1998; Kwiatkowska 2006; Belzyt 2015)13.

Warto w tym miejscu zwrócić uwagę, iż przywołane powyżej elementy Komunikacja-Ciało-Emocje wspólnie tworzą akronim „KCE”, brzmieniem przypominający słowo „chcę”. Nie jest to przypadek, bowiem słowo „chcę” oraz intencja i znaczenie z nim związane są niezwykle ważnym celem działań terapeutycznych. Na wywołanie aktywności, pobudzenie (przebudzenie) poczucia sprawczości (sprawstwa), dążenie do tego, aby osoba była zdolna do zakomunikowania swoich potrzeb - wyraziła swoje „chcenie” („KCEnie”) - nakierowane jest większość z prowadzonych terapii.

Parafrazując znane powiedzenie „Yes, I can”, można wykorzystać akronim Aplikacji KCE do stworzenia wersji „Tak, ja KCE” (Tak, ja chcę).

W tym miejscu chciałabym powrócić do przedstawiania koncepcji (aplikacji) KCE i jej funkcjonowania. Jak starałam się wykazać powyżej elementy Aplikacji KCE wzajemnie oddziałują na siebie, przenikają się. Nie mają stałego przepływu jednostronnego.

W związku z tym uważam, że warto wskazać na ich wzajemne zależności i oddziaływania między nimi, dodając do powyższego rysunku (rys. 1) elementy pokazujące dynamikę tych działań.

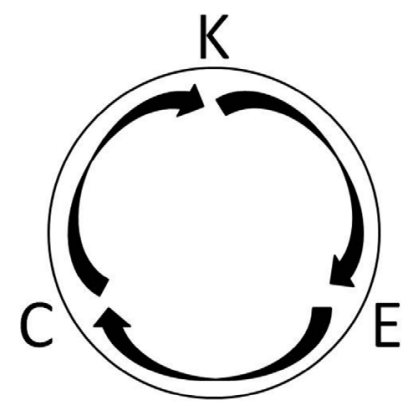

Rys. 1.

Źródło: Opracowanie własne.

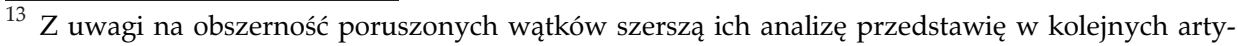
kułach. 


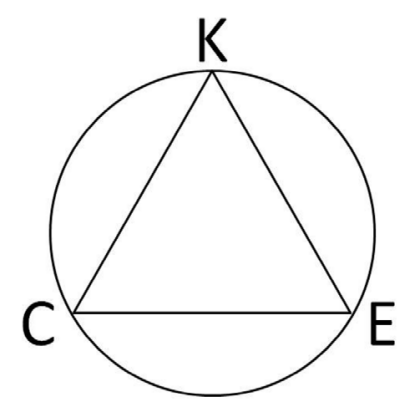

Rys. 2.

Źródło: Opracowanie własne.

Powyższe graficzne przedstawienie (rys. 2) nie jest jedynym jakie może wskazywać na zależności pomiędzy poszczególnymi elementami.

Poniżej (rys. 3) ujęcie rozkładu sił Aplikacji KCE wskazuje, iż każdy z obszarów: Komunikacja-Ciało-Emocje może funkcjonować osobno, w oderwaniu od innych. Sytuacja taka ma miejsce, kiedy osoba działa tylko w jednym z obszarów, odcinając się od pozostałych, czym skazuje się na dyskomfort, bowiem jedynie połączenie i spójne współdziałanie umożliwiają sprawne i optymalne funkcjonowanie.

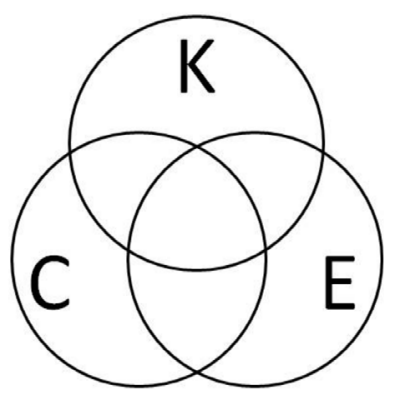

Rys. 3.

Źródło: Opracowanie własne.

W toku analiz oraz planowanych badań, uważam, że najwłaściwsze byłoby zespolenie części przedstawiających relacje między elementami KomunikacjaCiało-Emocje.

Oddziaływania między poszczególnymi elementami Aplikacji KCE są bowiem zależne od siebie i trwają w czasie (są nieustannie), więc całość obrazu warto uzupełnić, aby ukazać układ tych sił i zależności oraz pól oddziaływania. 
W wyniku tych rozważań powstała figura łącząca te niezwykle istotne w mojej ocenie siły:

- wzajemne oddziaływanie,

- wzajemna zależność,

- nieustanne oddziaływanie,

- nakładanie i przenikanie się pól.

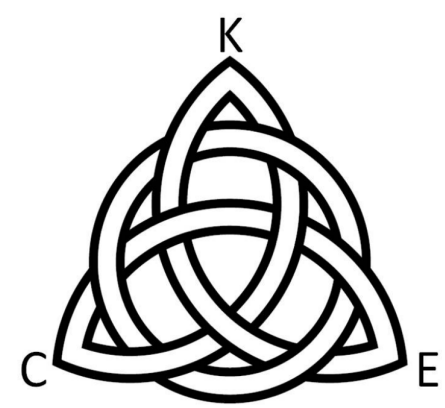

Rys. 4.

Źródło: Opracowanie własne.

Aplikacja KCE zawiera w sobie jeszcze jedno znaczenie - uświadamia, iż poza intencją sprawstwa wpisaną w działania związane z Komunikacją-Ciałem-Emocjami, którą wyraża sparafrazowane hasło „Tak, ja KCE (chcę)”, również jasno ukazuje, iż każdą osobę można uznać za swoiste ucieleśnienie komunikacji i emocji, bowiem nie można się nie komunikować (komunikujemy się nieustannie).

„Tak, ja (jestem) KCE - Komunikacją, Ciałem, Emocjami”.

Wykorzystanie „aplikacji” jako dopełnienia pojęcia modelu

Rozważając określenie jakim mogłabym nazwać zaproponowany sposób połączenia trzech elementów istniejących od dawna, ale często postrzeganych jako osobne (niezależne od siebie, oddzielone od siebie), przychodziły mi na myśl różne określenia, $\mathrm{m}$. in. model czy koncepcja. Uznałam je jednak za terminy zbyt często wykorzystywane, a także mające znamiona konstruktu teoretycznego, podczas gdy mnie zależy na połączeniu wymiaru teoretycznego z praktycznym i wdrożeniu w działania terapeutyczne.

Przedstawione rozważania można by określić mianem „modelu”, niemniej model postrzegany jako teoretyczny opis rzeczywistości bazujący na obserwacji rzeczywistości, który opiera się na wnioskowaniu z historycznych danych nie daje gwarancji poprawności działania w przyszłości. Model jako konstrukt jest za- 
korzeniony w przeszłości i cechuje go stałość, co powoduje, że nie można w pełni liczyć na jego sprawdzalność w teraźniejszości czy przyszłości, podczas zmieniających się warunków czy danych. Wskazania te stały się powodem do poszukiwania innego określenia, które stwarzałoby przestrzeń do modyfikacji wraz z nabywaniem wiedzy, doświadczenia i dostarczanych danych będących wynikiem przeprowadzanych badań $\mathrm{i}$ analiz.

Pojęciem, które spełnia oczekiwania w warstwie znaczeniowej jest aplikacja. Aplikacja wskazuje ciekawą perspektywę postrzegania zjawisk, sytuacji i doświadczeń - pokazuje jak to, co istnieje, to, co jest dostępne można wykorzystać w nowej formie, wskazać inny punkt widzenia, inny sposób wykorzystania, a tym samym odpowiedzieć na potrzebę użytkowników.

Aplikacja, zdaniem P. Kwiatka $(2019,2016)$, wykorzystującego to pojęcie do projektowania narzędzi terapeutycznych do działań w obszarze interwencji pozytywnych, powinna mieć użyteczne działanie pomocowe.

Aplikacja jest przeze mnie rozumiana jako zbiór funkcjonalności, które mogą istnieć niezależnie od siebie i same w sobie odpowiadają na pewne potrzeby odbiorcy, ale dopiero zestawione $\mathrm{w}$ jednym programie/aplikacji w pełni (całościowo) odpowiedzią na potrzebę użytkownika. Niezaprzeczalną wartością aplikacji jest to, że połączenie zbioru wspomnianych elementów (funkcji) w efekcie daje więcej niż suma poszczególnych korzyści płynących z każdej z nich osobno. Aplikacja jest więc całością pewnych funkcjonalności, a dzięki temu odpowiada kompleksowo na potrzeby.

Kolejnym argumentem za wykorzystaniem do określenia prezentowanych założeń mianem "aplikacji” jest to, że aplikacja powiązana jest z funkcjonowaniem i działaniem - musi być wdrożona. Aplikacja w procesie powstawania przechodzi przez kolejne etapy cyklu wytwórczego (rys. 5).

Przedstawiony w pierwszej części tekstu zamysł połączenia postrzegania Komunikacji, Ciała, Emocji jako elementów połączonych i wspólistniejących przy analizie teoretycznej oraz projektowaniu badań, mógłby zostać określony jako "model" (model KCE). Celem podjętych działań jest wypracowanie na podstawie wspomnianych trzech elementów "narzędzia"14 terapeutycznego przeznaczonego na potrzeby osób pracujących z osobami z niepełnosprawnościami, spełniającego wymogi aplikacji - odpowiadającego potrzebom użytkowników, funkcjonalnego, elastycznego i poddawanego modyfikacjom wraz ze zmianą warunków/ napływających danych.

$\overline{14}$ Określenie „narzędzie” z psychologii najczęściej kojarzone jest z wymiarem ilościowym i standaryzowaniem, natomiast w podjętym projekcie będzie miało wymiar jakościowy. Określenie to jest rozpoznawalne i bliskie znaczeniowo pojęciu, które będzie używane w projektowanym badaniu. Dla uniknięcia niejasności w definiowaniu, w tym artykule słowo "narzędzie" ujęte zostało w cudzysłów - szczegółowe wyjaśnienia terminów i znaczeń będą przedmiotem kolejnych artykułów. 


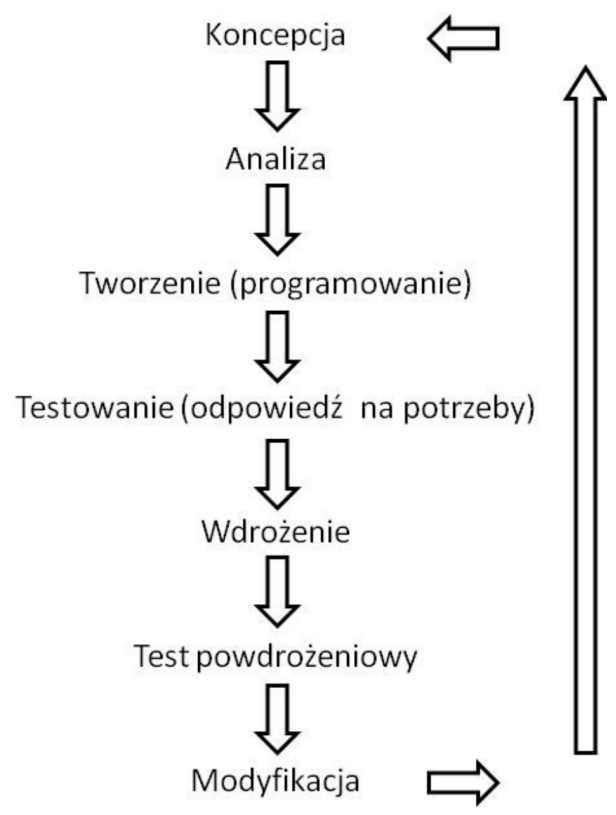

Rys. 5. Cykl wytwórczy procesu wdrażania aplikacji

Źródło: Opracowanie własne.

Przedstawiony artykuł miał na celu prezentację powstającego konstruktu teoretycznego i projektowanych badań wykorzystujących autorską koncepcję, której zamysłem jest powstanie aplikacji KCE - połączenia trzech elementów (Komunikacja-Ciało-Emocje) dla stworzenia jakościowego „narzędzia” terapeutycznego. Możliwość pracy nad jego zaprojektowaniem pojawiła się wraz ze zmianą perspektywy postrzegania obszarów będących w polach moich zainteresowań.

\section{Bibliografia}

Arnold M.B. (1960), Emotion and personality: Psychological aspects, Oxford.

Baran J., Mikrut A. (2007) (red), Umiejętności komunikacyjne osób z niepetnosprawnościa. Teoria, diagnoza, wspomaganie, Wydawnictwo Naukowe AP, Kraków.

Belzyt J. (2005), Kontakt i komunikacja z osobami niepetnosprawnymi. Aspekty niewerbalne, Uniwersytet Mikołaja Kopernika, Torun.

Belzyt J. (2005a), Profil idealnego terapeuty, czyli jakimi osobami chcieliby być za kilka lat studenci Pedagogiki? [w]: „Nasze Dzieci” 4, Redakcja Wydawnictw Tyflologicznych Polskiego Związku Niewidomych, Warszawa.

Belzyt J. (2016a), Wykorzystanie wiedzy o umyśle dla funkcjonowania osób z zaburzeniami/niepetnosprawnością zmysłu wzroku, Niepełnosprawność. Dyskursy Pedagogiki Specjalnej, 21. 
Belzyt J., Badera J. (2018), Cylinder of conflict' as an extended model of environmental conflicts in the context of mining activity, November 2018, Biuletyn - Państwowego Instytutu Geologicznego, 472.

Belzyt J., Woynarowska A., Doroszuk J. (2015), Doświadczenia niepetnosprawności w przestrzeniach spotkania, Wydawnictwo Katedra, Gdańsk.

Belzyt J. (2005b), Krzyś idzie do szkoły. Rola rodziców i nauczycieli w budowaniu prawidłowych relacji dziecka z niepetnosprawnościa wzroku w szkole [w]: Nasze Dzieci 6, wyd. Redakcja Wydawnictw Tyflologicznych Polskiego Związku Niewidomych, Warszawa.

Belzyt J. (2005c), Przykłady kontaktu z osobami z niepetnosprawnościq wzroku [w]: Nasze Dzieci 5, Redakcja Wydawnictw Tyflologicznych Polskiego Związku Niewidomych, Warszawa.

Belzyt J. (2005d), Zasady efektywnej wspótpracy pomiędzy nauczycielami a rodzicami dziecka niepetnosprawnego [w] Nasze Dzieci 7, Redakcja Wydawnictw Tyflologicznych Polskiego Związku Niewidomych, Warszawa.

Belzyt J. (2013), Niewerbalne aspekty relacji z Innym w ujęciu psychologicznym [w:] Miejsce Innego we wspótczesnych naukach o wychowaniu. W poszukiwaniu pozytywów, I. Chrzanowska, B. Jachimczak, K. Pawelczak (red.), Wydawnictwo Naukowe UWM, Poznań.

Belzyt J. (2013a), Życie ze skazą. Oczekiwania społeczne osób z nabytą niepełnosprawnościa (oszpeceniem), Szkice Humanistyczne. Kwartalnik naukowy, t. 13 (1).

Belzyt J. (2016), Ciało w sytuacji niepełnosprawności - kontrola, odrzucenie i działania terapeutyczne, Niepełnosprawność. Dyskursy Pedagogiki Specjalnej, 16.

Belzyt J. (2017), The relationship with the Other as a platform for discussion about conflicts. Comments on the Orzesze coal mine project, Environmental \& Socio-economic Studies, 2.

Berger, B. (2007). SFA w praktyce szkolnej [w:] Klient ekspertem. Podejście Skoncentrowane na Rozwiązaniach i jego zastosowanie w Polsce, J. Kienhuis, T. Świtek (red.), Kraków.

Błajet P (2006), Ciało jako kategoria pedagogiczna. W poszukiwaniu integralnego modelu edukacji, Wydawnictwo UMK, Torun.

Cornelius R.R. (1996), The science of emption: Research and tradition in the psychology of emotions, New York.

Denham S. (1998), Emotional Development in Young Children, Guilford Press, New York.

Ellis A. (2008), Gtębokie uzdrawianie emocji, Zielona Sowa, Kraków.

Fredrickson B. (2011), Pozytywność, Zysk i s-ka.

Fröhlich A. (1998), Stymulacja od podstaw. Jak stymulować rozwój osób głęboko wielorako niepetnosprawnych, WSiP, Warszawa.

Grycman M (2014), Porozumiewanie się z dziećmi ze złożonymi zaburzeniami komunikacji. Poradnik nie tylko dla rodziców.

Halbenstadt, Denham, Dunsmore, (2001), Affective social competence, Social Development, 10 (http://www.isce.vt.edu/files/ASC\%20target.pdf).

Jong de P., Berg I.K (2007), Rozmowy o rozwiązaniach: podręcznik dla trenerów, Księgarnia Akademicka, Kraków.

Krasiejko I. (2009), Podejście Skoncentrowane na Rozwiąaniach w edukacji, Podstawy Edukacji, 2. Kwiatek P. (2016), Cztery okna wdzięczności. Jak odzyskać petnię radości, Serafin, Kraków.

Kwiatek P. (2019), wykłady i warsztaty „Interwencje pozytywne w praktyce pomocowej”, Uniwersytet SWPS, Sopot. 
Kwiatek P., Wilczewska K. (2015), Czym jest a czym nie jest psychologia pozytywna? Poszukiwania paradygmatu, Seminare, 36 (4).

Kwiatkowska M. (2006), Zwyczajne towarzyszenie zamiast specjalnej troski, CMPPP, Warszawa.

Lubomirsky S. (2011), Wybierz szczęście. Naukowe metody budowania życia, jakiego pragniesz, Laurum.

Peterson Ch., Seligman M. (2004), Character Strengths and Virtues, Oxford University Press, Oxford.

Piszczek M. (2006), Diagnoza i wspomaganie rozwoju dziecka. Wybrane zagadnienie, CMPPP, Warszawa.

Rosenberg M. (2003), Porozumienie bez przemocy: o języku serca, Jacek Santoski \& Co, Warszawa.

Rosenberg M. (2008), Edukacja wzbogacajaca życie, Fundacja Świadomego Rozwoju, Warszawa.

Saarni C. (1999), The Development of Emotional Competence, New York.

Schaffer H.R. (2004), Psychologia dziecka, Warszawa.

Seligman M., Csikszentmihalyi M. (2000), Positive Psychology - An Introduction, American Psychologist, 55 (1).

Seligman M. (2011), Flourish: A Visionary New Understanding of Happiness and Well-being, Free Press, New York.

Shulz von Thun F. (2001-2007), Sztuka rozmawiania, część 1-4, WAM, Kraków.

Sroufe L.A. (1996), Emotional Development, Cambridge University Press, Cambridge.

Turner J.H., Stets J.E. (2009), Socjologia emocji, Warszawa.

Tyralik-Kulpa E. (2016), Ewka, co cię ugryzło. Jak się zrozumieć i porozumieć, Co ja na to, Warszawa.

Waldenfels B. (2002), Topografia obcego, studia z fenomenologii obcego, Warszawa.

Waldenfels B. (2009), Podstawowe motywy fenomenologii obcego, Warszawa.

Zaorska M. (2012) (red), Komunikacja alternatywna osób głuchoniewidomych, Akapit, Torun.

Zimbardo P. (1996), Psychologia i życie, PWN, Warszawa. 